\title{
Physico-chemical Properties of Mechanically Extracted Banana Juice at Different Ripening Stages
}

\author{
Mathayo G Mathias*, Lilian D Kaale and Oscar Kibazohi \\ Department of Food Science and Technology, University of Dar es Salaam, P.O. Box 35134 \\ Dar es Salaam, Tanzania \\ E-mail addresses: mashinagwi@gmail.com; elykaale@gmail.com; kibazohi@yahoo.com \\ Received 9 Feb 2021, Revised 16 Oct 2021, Accepted 23 Oct 2021, Published Dec 2021
}

DOI: https://dx.doi.org/10.4314/tjs.v47i5.10

\begin{abstract}
This paper presents the findings of a study on physico-chemical properties of low viscosity banana juice from five banana cultivars: Pisang Awak (PSA) an ABB genome, Yangambi km5 (YKM5) an AAA genome and cultivars from AAA-EA genome, namely Mbilabile, Ndeshi and Mlonga. Low viscosity banana juice was extracted using improved mechanical method at five ripening stages. The physico-chemical properties significantly varied according to cultivars and ripening stages $(p<0.05)$. Yields, total soluble solids (TSS), titratable acidity (TA) and $\mathrm{pH}$ were in the range of $19.50-74.03 \%, 7.33-27.64{ }^{\circ}$ Brix, $0.37-0.76 \%$ malic acid equivalent and 4.09-4.70, respectively. Yields decreased in the order of Mbilabile > Ndeshi > Mlonga > YKM5 > PSA whereas the total soluble solids increased as follows Mlonga $<$ Mbilabile < Ndeshi < YKM5 < PSA. Furthermore, ashes and mineral contents decreased with ripening stages whereas the low viscosity banana juice was rich in potassium and magnesium. Finally, the study recommends stage 5 of the ripeness as ideal for producing low viscosity banana juice.
\end{abstract}

Keywords: Mechanical extraction, Banana cultivar, Ripening stage, Tannin, Banana juice.

\section{Introduction}

Banana is widely consumed as staple food in the world. In fact, it is among the four largest sources of carbohydrates in East Africa alongside cassava, maize and rice (Bechoff et al. 2020). In Tanzania, green bananas are cooked for food, ripe bananas are roasted or eaten raw as dessert or processed into juice (Karamura et al. 2012). Bananas are perishable due to high moisture content. As a result, value addition to produce products such as banana flour, figs, pastilyas, wine and juice, is vital for reducing banana post-harvest losses which are more than 20\% (NPHMS 2019) of 3.4 million metric tonnes of banana production in Tanzania (FAOSTAT 2019). The endemic East African highland banana varieties of genotype AAA-EA and exotic banana of genotypes $\mathrm{ABB}$ and $\mathrm{AB}$, are varieties suitable for juice production (Gensi et al. 1994).

Low viscosity banana juice has exclusively been produced using mechanical process in East Africa for several centuries. The process involves kneading of a mixture of ripe bananas and grass or fibres to squeeze juice out of the pulp (Gensi et al. 1994, Kyamuhangire et al. 2002). However, recent technical development has enabled this mechanical process to extract banana juice by prolonged mashing and pressing pulp without using grass or fibres (Kibazohi et al. 2017, Majaliwa et al. 2019). The improved process is more hygienic and easier to scale up. While the banana juice can also be produced by enzymatic and hot extraction methods, the mechanical process is the most efficient in terms of time and cost-effectiveness (Kyamuhangire et al. 2002, Byarugaba- 
Bazirake 2008, Tapre and Jain 2014, Lee et al. 2006). Apparently, low viscosity banana juice is produced from banana cultivars with high tannin content (Kyamuhangire et al. 2006). Mechanism of low viscosity banana juice release appears to involve formation of insoluble complexes of tannins, protein and polysaccharides resulting in juice release (Kyamuhangire et al. 2006, Kibazohi et al. 2017, Majaliwa et al. 2021). The new scalable low viscosity banana juice extraction technology has a huge potential for commercialisation of banana juice, hence the need to characterise banana juice from different cultivars and juice property variations with ripening stage.

Kyamuhangire et al. (2002) and Byarugaba-Bazirake (2008) described characteristics of low viscosity banana juices. Banana juices extracted using traditional mechanical method from different cultivars contain protein, sugars, organic acids and minerals such as potassium, magnesium, phosphorus and sodium (Gensi et al. 1994, Ssamula et al. 2015). Banana juices produced from Kayinja (Pisang Awak) cultivar from Uganda by enzymatic and traditional mechanical extraction methods were $60.4 \%$ and $75.7 \%$, TSS of 34.9 and $30.7{ }^{\circ}$ Brix, respectively (Kyamuhangire et al. 2002).

There is limited study on the extraction of low viscosity banana juice using improved mechanical method. Moreover, studies on juice extraction using traditional mechanical methods have mainly focused on Pisang Awak. In addition, there is limited knowledge on juice characteristics from other banana cultivars. Thus, the current development in the production of low viscosity banana juice necessitates understanding the influence of both cultivars and ripening stages on the physico-chemical properties of banana juice.

\section{Materials and Methods Banana samples}

Pisang Awak (PSA) originating from Mbeya in Tanzania's Southern Highlands was collected from Mabibo market in Dar es Salaam; Yangambi Km5 (YKM5) and Mbilabile were collected from Kagera, the northwest region of Tanzania; while Ndeshi and Mlonga were sourced from Kilimanjaro region, north of the country. The banana bunches were collected at either stage 1 or stage 2 of ripening and brought to the Food Laboratory, Department of Chemical and Mining Engineering, University of Dar es Salaam. At the laboratory, they were ripened at an ambient temperature of $26 \pm 2{ }^{\circ} \mathrm{C}$ to stages 3 to 7 of ripeness as illustrated on the commercial visual chart in Figure 1 (Tapre and Jain 2012).

\section{Juice preparation}

Banana fingers in bunches were plucked and washed with clean water to remove any dirt and about $1000 \mathrm{~g}$ of banana pulp was blended using an electric blender (Model Robot coupe blixer 4 V.V) for 2-10 minutes at $1200 \mathrm{rpm}$ until juice started oozing as described by Majaliwa et al. (2019). Then juice was pressed using hands through clean filter cloth to obtain clear juice. Extracted juice was packed in glass bottles and stored in a deep freezer at $-18^{\circ} \mathrm{C}$ prior to analysis within 24 hours.

\section{Banana juice property analyses}

Low viscosity banana juice yield was obtained by dividing the amount of juice produced to the weight of peeled banana that was mashed to produce the juice. The total soluble solids in juices were measured as ${ }^{\circ}$ Brix at $20^{\circ} \mathrm{C}$ using the Hand-Held Refractometer with temperature compensation (MT-032ATC, Three-In-One Co., Taiwan). Titratable acidity (TA) was assayed by diluting $10 \mathrm{~mL}$ of juice with 40 $\mathrm{mL}$ of distilled water and titrated against 0.1 $\mathrm{M}$ sodium hydroxide using phenolphthalein indicator till stable pale pink colour was observed. Titratable acidity was expressed as a malic acid equivalent in the percentage of the juice sample. The juice $\mathrm{pH}$ was measured using the $\mathrm{pH}$ meter (Model HI 98129 HANNA instruments Woonsocket RI USA and Romania). 


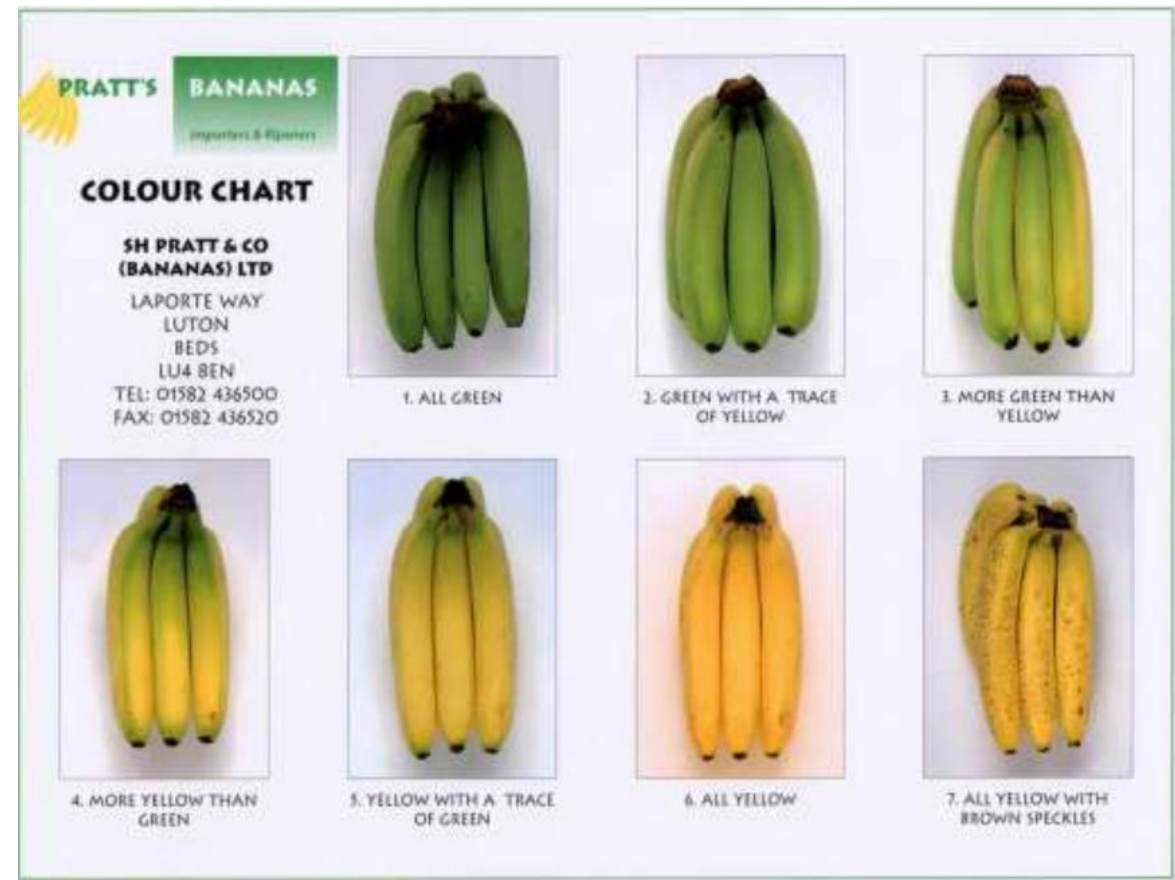

Figure 1: Standard commercial colour chart for ripening stages categorisation. The commercial colour chart illustrates that; stage $1=$ All green, stage $2=$ Green with a trace of yellow, $3=$ More green than yellow, $4=$ More yellow than green, $5=$ Yellow with a trace of green $6=$ All yellow, $7=$ All yellow with brown speckles.

Ash content was measured using the AOAC (1990) method number 945.39 albeit with some modifications. Five grammes $(5 \mathrm{~g})$ of a juice sample were weighed by analytical balance $(\mathrm{m})$ in pre-ignited, tarred crucible of mass $\left(\mathrm{m}_{1}\right)$. The liquid was evaporated on a hot plate set at $100{ }^{\circ} \mathrm{C}$ for 30 minutes and then ignited in the muffle furnace (Model Nabertherm GmbH Bahnhofstr. 20, 28865 Lilienthal/Bremen Germany) at $550{ }^{\circ} \mathrm{C}$ for 2 hours. The crucibles with sample ashes were transferred to desiccators and left to cool for about 30 minutes and weighed $\left(\mathrm{m}_{2}\right)$. The ash content was evaluated using the following formula:

$$
\text { Ash content }(\%)=\frac{m_{2}-m_{1}}{m} \times 100 .
$$

Mineral contents were determined based on the AOAC (1990) standard method. Ten (10) $\mathrm{mL}$ of a juice sample were mixed with $25 \mathrm{~mL}$ of $25 \% \mathrm{HCl}$. The mixture was then diluted with deionised water to $100 \mathrm{~mL}$. Potassium $(\mathrm{K})$, magnesium $(\mathrm{Mg})$, calcium $(\mathrm{Ca})$, sodium $(\mathrm{Na})$, zinc $(\mathrm{Zn})$ and iron $(\mathrm{Fe})$ were determined using atomic absorption spectrometer (Varian AA240 equipped with SpectrAA worksheetoriented AA Software Version 5.01).

\section{Statistical analysis}

Juice preparation samples were in triplicates at either 4 or 5 levels of ripening stages for all the five cultivars. The analysis of variance (ANOVA) was performed using Minitab 17, with sample means subjected to Tukey pairwise comparisons.

\section{Results and Discussion Yields of banana juice}

Banana juice extraction occurred at varying ripening stages from stage 3 to stage 7. The juice yields among different cultivars significantly differed at $p<0.05$ (Figure 2). At stage 3, yields were $49.31 \%, 55.07 \%$, $19.5 \% 45.62 \%$, and $38.47 \%$ for Mbilabile, Ndeshi, Mlonga, YKM5 and PSA, respectively. The juice yields increased with the ripening stages from stage 3 to stage 5 and decreased between stage 5 and stage 7 except 
for PSA whose yields increased up to stage 6 . The highest yields observed at stage 5 for Mbilabile, Ndeshi, Mlonga and YKM5 were $74.03 \%, 67.35 \%, 64.48 \%$ and $59.60 \%$, respectively, whereas the highest yield for PSA was $47.80 \%$ at stage 6 . Juice yields decrease after stage 5 of ripeness was 1.20 to $33.40 \%$ for all cultivars except Mlonga whose juice yield drastically decreased by $69.75 \%$ from stage 5 to stage 6 and eventually, resulted in juice extraction failure. Juice extraction failure was also observed for YKM5.

The juice extraction failure implies production of high viscosity puree instead of low viscosity clear juice separation from the solid pulp. Juice extraction failure by a mechanical method is likely due to decrease in tannins with ripening. Kyamuhangire et al. (2006) reported juice extraction failure due to low tannins contents in banana, and Kibazohi et al. (2017) reported juice extraction failure as the tannin contents decreased below $0.68 \%$ in PSA during ripening.

Results from this study suggest that, juice yields for East African highland banana (Mbilabile, Ndeshi and Mlonga) are higher than those for exotic bananas (PSA and
Yangambi km5). The difference could be attributable to the genotype composition of cultivars (Lokesh et al. 2014).

\section{Total soluble solids (TSS)}

Total soluble solids varied among the cultivars and increased with the ripening stages, ranging from 7.33 to $27.64{ }^{\circ} \mathrm{Brix}$ (Figure 3). There was a significant increase in TSS from stage 3 to stage 7 of ripeness for all the cultivars except Mbilabile $(p<0.05)$. The highest values of TSS observed at stages 6 and 7 just before the banana juice extraction failure. Increase of TSS during ripening is associated with enzymatic conversion of starches to simple sugar, a normal process that happens during ripening (Hill and Rees 1993, Cordenunsi and Lajolo 1995).

The exotic varieties (PSA and YKM5) have higher TSS than East African highland banana varieties (Mbilabile, Ndeshi and Mlonga); PSA had the highest, $27.69{ }^{\circ}$ Brix followed by YKM5 $23.69^{\circ}$ Brix compared to Ndeshi $19.98^{\circ}$ Brix, Mbilabile $18.82^{\circ}$ Brix and Mlonga $14.33{ }^{\circ}$ Brix. Implicitly, cultivar variations of banana might account for the observed differences.

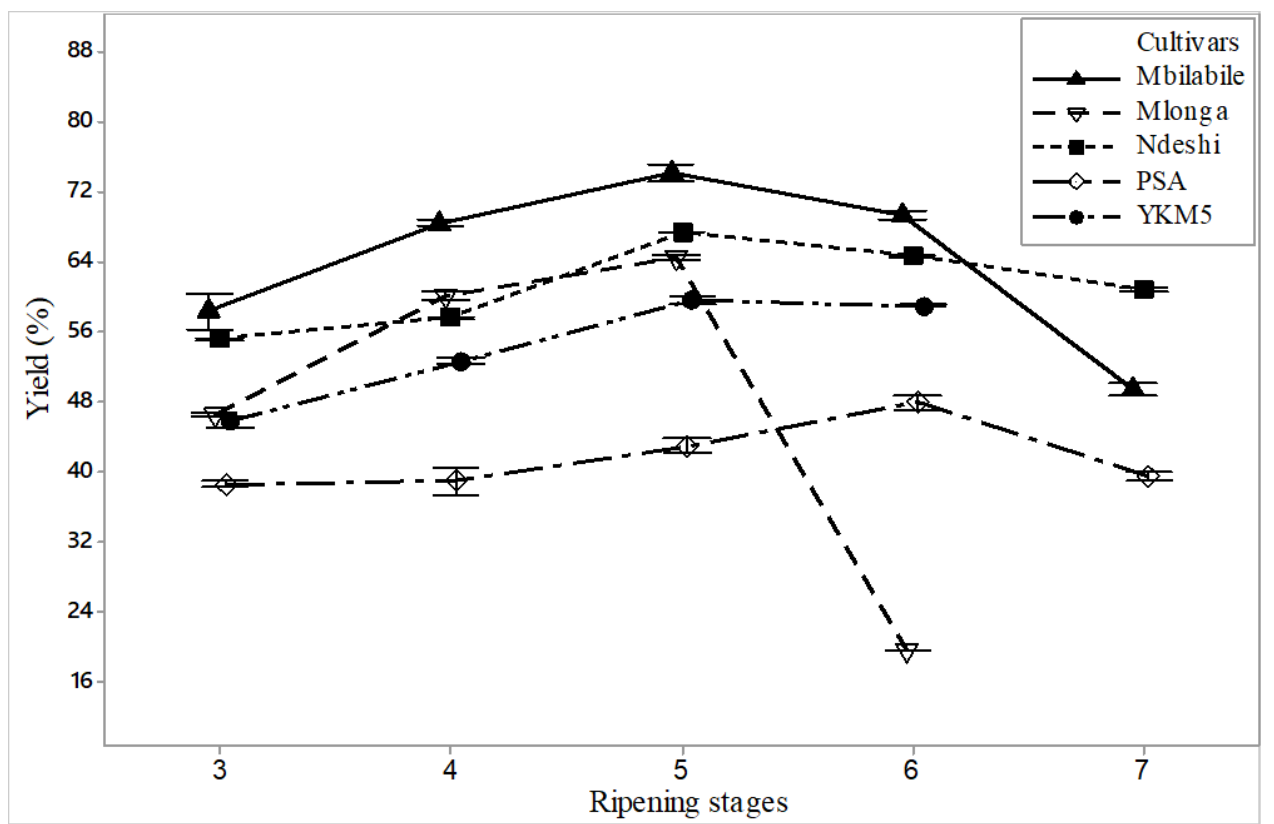

Figure 2: Yields of banana juice at different stage of ripeness from different banana cultivars. 


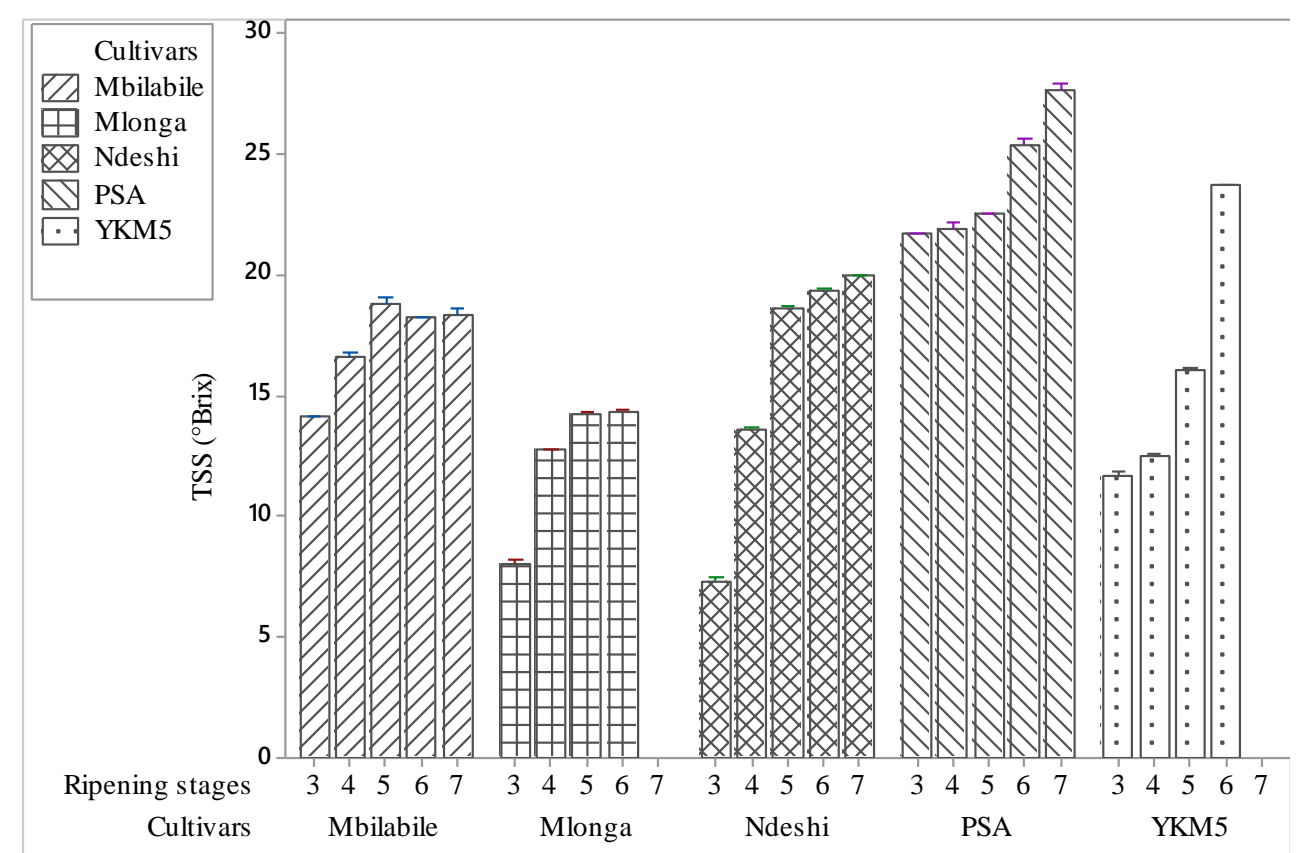

Figure 3: Total soluble solids contained in banana juices from different banana cultivars.

The amount of TSS contents in banana juices of Mbilabile (mbidde) and PSA (kayinja) extracted in this study corresponded well with 20.0 and $27.0^{\circ}$ Brix of Mbidde (mbilabile) and Kayinja reported by Ssamula et al. (2015) and Kyamuhangire et al. (2002). However, the total soluble solids of Yangambi km5 were higher at $23.69^{\circ} \mathrm{Brix}$ than that reported in literature at $17.0^{\circ} \mathrm{Brix}$ (Ssamula et al. 2015).

Although the extraction was similar, the difference in TSS appears to be attributable to extraction methods. The improved method of blending is capable of rupturing many cells to release sugars compared to the kneading action used in Ssamula et al. (2015) study. In addition, Kyamuhangire et al. (2002) reported the highest value at $34.9^{\circ} \mathrm{Brix}$ and $30.7^{\circ} \mathrm{Brix}$ for PSA (Kayinja) juice extracted using the enzymatic method and traditional mechanical method, respectively.

\section{Titratable acidity (TA)}

The amounts of TA in banana juice were $0.37-0.76 \%$ equivalent to malic acid (Figure 4). The TA in banana juice did not show significant difference for both PSA and
YKM5, but for other cultivars significant decrease was observed for Mbilabile, Ndeshi and Mlonga $(p<0.05)$ after stage 5. The TA across ripening were as follows: YKM5 0.68 $0.72 \%$ malic acid, Ndeshi $0.48-0.76 \%$ malic acid, Mbilabile $0.44-0.66 \%$ malic acid, Mlonga $0.52-0.65 \%$ malic acid and PSA $0.37-0.44 \%$ malic acid from stages 3 to 7 , respectively.

The trend of titratable acidity in banana juice increased from stage 3 to stage 4 for Mlonga and stage 5 for Mbilabile, Ndeshi and YKM5 with increase in ripeness of the banana fruits. There was a similar drop in titratable acidity trend from stage 5 to stage 7 for Ndeshi, YKM5 and Mbilabile, while for the Mlonga's titratable acid dropped from stage 4 to stage 6 . However, PSA registered the opposite trend with notably lowest titratable acidity of $0.37 \%$. The increase in TA is associated with rising enzymatic activities to full ripeness before senescence (Chen et al. 2009). Newilah et al. (2009) reported an increase in titratable acidity of cooking bananas and a similar trend for dessert cultivars with increase in ripening stages. 


\section{Changes of $\mathbf{p H}$ in banana juice}

The $\mathrm{pH}$ of banana juice acidity ranged 4.09-4.70 (Figure 5). The changes in $\mathrm{pH}$ observable during ripening were as follows: Mbilabile 4.15-4.45, PSA 4.15-4.38, YKM5 4.14-4.42, Ndeshi 4.13-4.70 and Mlonga 4.09-4.47. The changes of $\mathrm{pH}$ indicated significant differences $(p<0.05)$ at different stages of banana ripeness for all cultivars. The $\mathrm{pH}$ for Ndeshi, Mlonga, Mbilabile and YKM5 significantly slumped $(p<0.05)$ from stage 3 to stage 5 and then increased at stage 7 . Contrary, the $\mathrm{pH}$ of PSA increased from stage 3 to stage 4 before dropping at stage 7 . Mlonga had the lowest $\mathrm{pH}$ at stage 5, whereas Ndeshi had the highest $\mathrm{pH}$ value at stage 3 . The $\mathrm{pH}$ variations were associated with both TA contents and genetic makeup of a particular cultivar. A similar $\mathrm{pH}$ variation for dessert banana cultivars was reported by Newilah et al. (2009). Furthermore, a decreasing trend of $\mathrm{pH}$ from stage 2 to stage 3 and then rising to stage 7 has been reported in berangan bananas (Zulkifli et al. 2019).

\section{Ash content of banana juice}

The ash content of banana juice typically represents total minerals in banana juice. The ash contents in banana juices varied with cultivars and ripening stages in a range 0.57$1.67 \%$ (Figure 6). As ripening stages progresses to stage 7 , ash contents drops for Mbilabile 1.67-0.86\%, YKM5 1.46-1.37\%, Mlonga $1.06-0.64 \%$, Ndeshi $0.84-0.68 \%$ and PSA $0.76-0.57 \%$. The decrease in ash contents of banana juice significantly differed $(p<0.05)$ for Mbilabile, PSA and Mlonga. On the other hand, there was no significant variation of ash contents with ripening for YKM5 and Ndeshi. Similarly, low ash content of banana juice of $0.35 \%$ at stage 6 was reported by Akubor et al. (2003). Small values of ash contents in juice might be attributable to the juice extraction method, whereby spent pulps were removed, which certainly contributed to the observable variations. Ash contents decreased in the order of Mbilabile > YKM5 > Mlonga > Ndeshi $>$ PSA across cultivars.

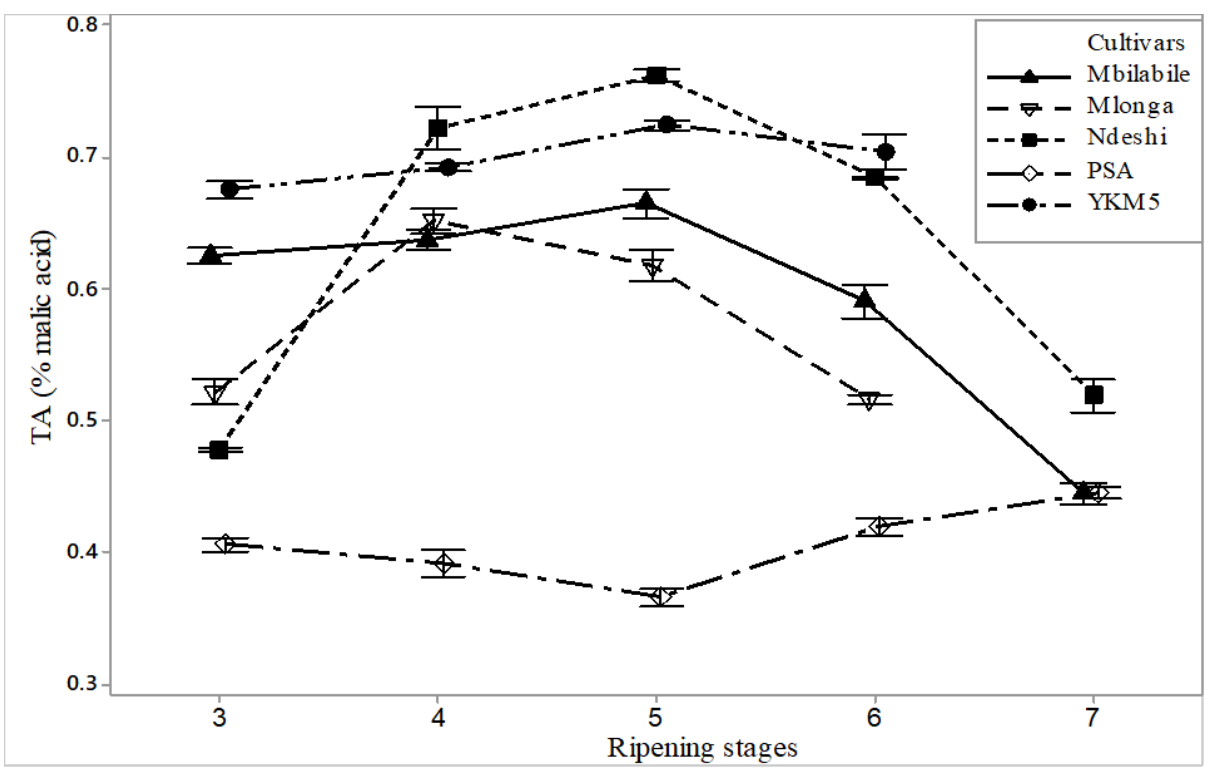

Figure 4: Titratable acidity of banana juice extracted from different banana cultivars. 


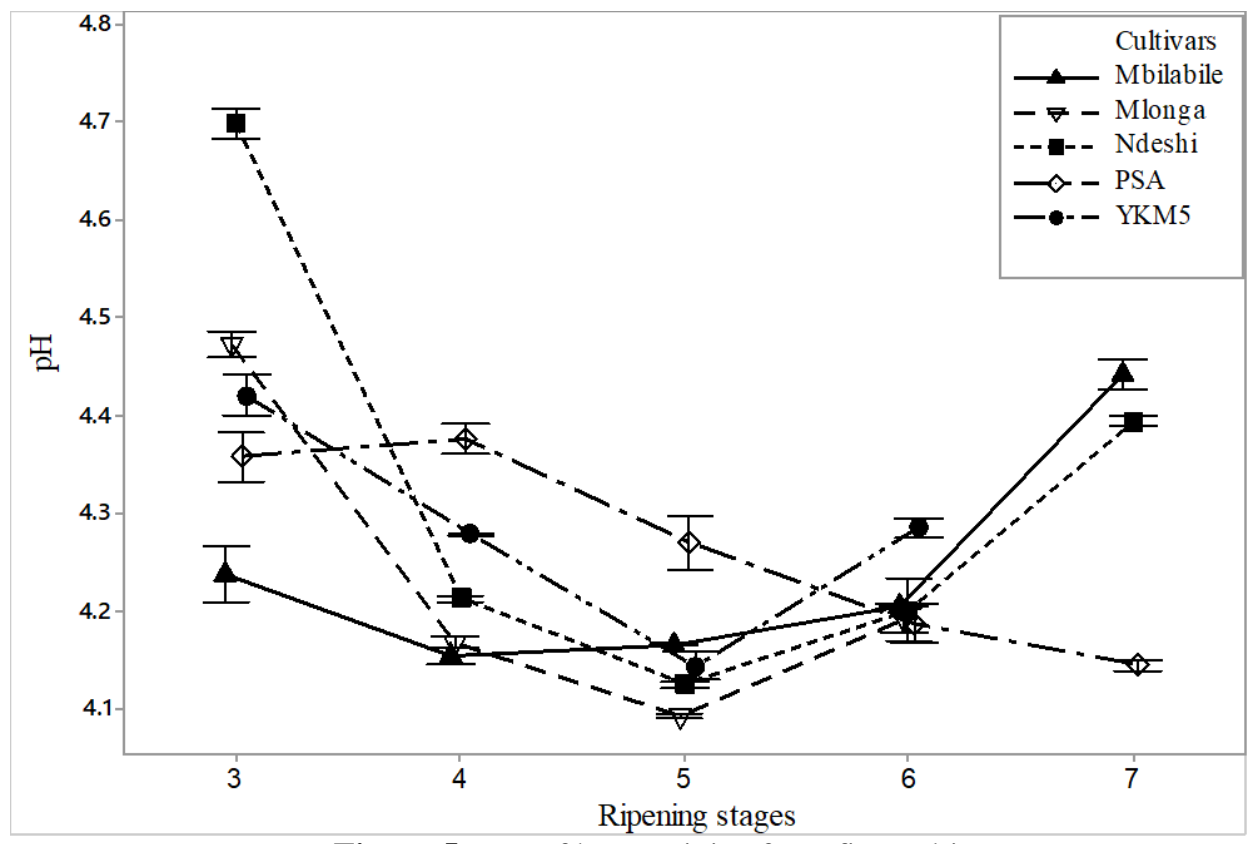

Figure 5: $\mathrm{pH}$ of banana juice from five cultivars.

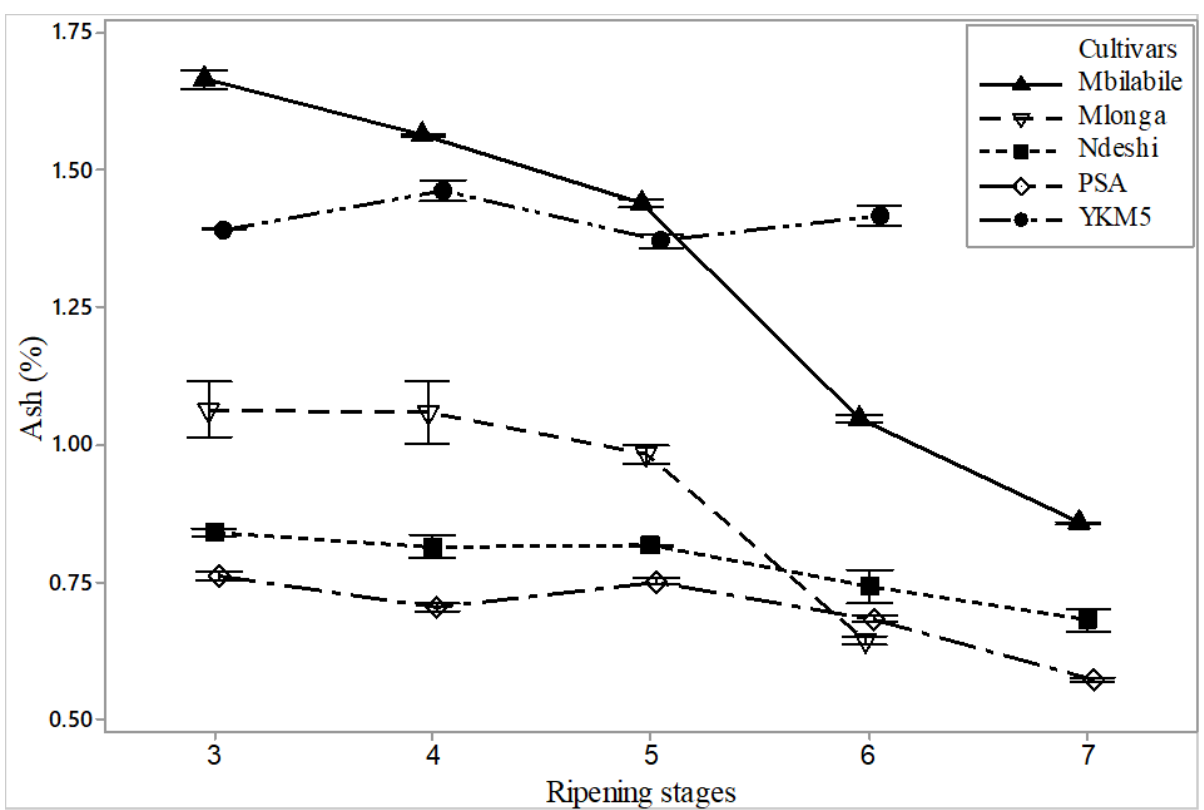

Figure 6: Ash content of banana juice from different banana cultivars.

\section{Mineral composition of banana juice}

The minerals of low viscosity banana juice were analysed (Table 1). The quantities of potassium were significantly high $(p<$ 0.05 ) for all the stages of ripeness in all cultivars except PSA and Mlonga. The amounts of potassium in banana juice from five banana cultivars ranged 11.77-13.15 g/L for Mbilabile, 4.20-5.09 $\mathrm{g} / \mathrm{L}$ for PSA, 14.50 $17.08 \mathrm{~g} / \mathrm{L}$ for YKM5, 7.96 - $9.60 \mathrm{~g} / \mathrm{L}$ for Ndeshi and 4.07-5.74 g/L for Mlonga (Table 1). The ripening stages in all cultivars 
indicated that there was no significant change $(p<0.05)$ of potassium contents with ripening in each cultivar.

On the other hand, there were significant differences of potassium contents $(p<0.05)$ among the cultivars. It emerged that potasium contents were higher for cultivars from Kagera than for those from Kilimanjaro and Mbeya regions. Variations of potassium contents in banana cultivars might be caused by agro-ecological zones reported, cultivar genomes and harvesting period (Bugaud et al. 2009). The potassium contents correlated well with $4.04 \mathrm{~g} / \mathrm{kg}$ and $2.94 \mathrm{~g} / \mathrm{kg}$ for Mbidde (Mbilabile) juice extracted by enzymatic and mechanical methods, respectively (Kyamuhangire et al. 2002). The amounts of potassium in PSA and Mlonga banana juice were similar to that reported for banana juice extracted using the enzymatic method from Enano gigante, FHIA-17 and FHIA 23 (Escalante-Minakata et al. 2013)

Table 1: Mineral contents $(\mathrm{mg} / \mathrm{L})$ of banana juice of five banana cultivars

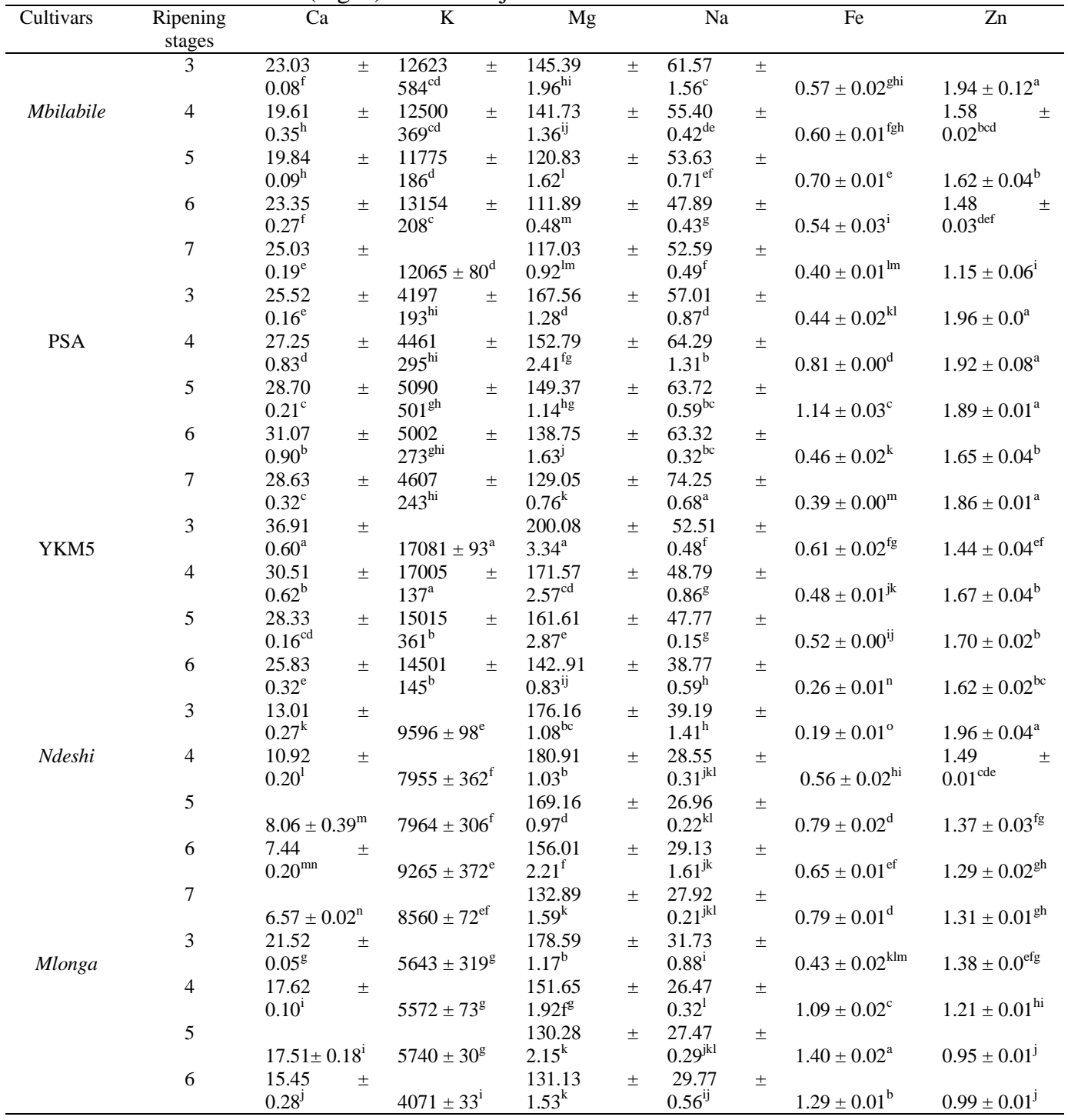

In each column across one cultivar, means with the same letter are not significant different $(p<$ 0.05 ) in accordance to Tukey pairwise comparisons. 
The amounts of magnesium in banana juice had a range of $113-200 \mathrm{mg} / \mathrm{L}$ in five banana cultivars (Table 1). The changes of magnesium content were insignificant for both YKM5 and Mlonga, but significant for PSA, Ndeshi and Mbilabile $(p<0.05)$ within cultivars. Magnesium contents decreased during ripening; Mbilabile $145-115 \mathrm{mg} / \mathrm{L}$, PSA 167-129 mg/L, YKM5 200-142 mg/L, Ndeshi 176-132 mg/L and Mlonga 178-131 $\mathrm{mg} / \mathrm{L}$ at stage 3 to stage 6 or stage 7 , respectively. Magnesium values were lower than the values reported in literature of 388.30-491.30 mg/L (Kyamuhangire et al. 2002, Wall 2006, Escalante-Minakata et al. 2013).

Apart from potassium and magnesium contents in banana juice, sodium contents ranged 26-74 $\mathrm{mg} / \mathrm{L}$ in five cultivars. Meanwhile, calcium contents ranged 7.44$36.91 \mathrm{mg} / \mathrm{L}$ in all cultivars. Zinc and iron contents ranged $0.946-1.958 \mathrm{mg} / \mathrm{L}$ and 0.191-1.404 $\mathrm{mg} / \mathrm{L}$, respectively. Based on recommended dietary allowance (RDA) for potassium and magnesium of $2000 \mathrm{mg} /$ day and $300 \mathrm{mg} /$ day, respectively, for a male adult human (Escalante-Minakata et al. 2013), low viscosity banana juice of $250 \mathrm{~mL}$ produced in this study can offer 50.9-147.2\% RDA of potassium and 9.4-11.9\% RDA of magnesium depending on the type of banana cultivar and ripening stage.

\section{Conclusion}

Low viscosity banana juice was successfully extracted from 5 banana cultivars. The banana juice yields increased with ripening stages up to stage 5 and decreased except for PSA. Physico-chemical properties of low viscosity banana juice vary depending on both cultivars and ripening stages. Low viscosity banana juice is rich in potassium and magnesium. Stage 5 of ripeness emerged in this study is the best ripening stage for producing low viscosity banana juice for all the cultivars as it offers not only the highest juice yield, but also nutritious juice with high mineral contents and dissolved solids (sugar). As this research focused on physico-chemical properties, there is a need for further study on other nutrients to explore even more potentials of low viscosity banana juice.

\section{Acknowledgements}

This study was conducted with funding from Sida of Sweden through the University of Dar es Salaam, Tanzania, within the subprogramme of 'Sustainable Agricultural Productivity-Processing and Value Chain to Enhance Food Security in Tanzania'.

\section{Conflict of Interest}

The authors declare no conflict of interest.

\section{Author contributions}

Conceptualisation: MG, LDK and OK Data curation: MG, LDK and OK Formal analysis: MG, LDK and OK Funding Acquisition: OK Investigation: $\mathrm{MG}$ and $\mathrm{OK}$ Project administration: OK Resources: OK Supervision: OK and LDK Validation; MG, LDK and OK Visualisation: MG, LDK and OK Roles/Writing-original draft: MG Writing-review \& editing: MG, LDK and OK. All authors read and agreed for the submission of manuscript.

\section{References}

Akubor P, Obio S, Nwadomere K and Obiomah E 2003 Production and quality evaluation of banana wine. Plant Foods Hum. Nutr. 58: 16.

AOAC 1990 Helrich K (Ed.) Official methods of analysis. $15^{\text {th }}$ ed, Association of Official Analytical Chemists, Inc. Arlington, VA, USA.

Bechoff A, Forsythe L, Njau M, Martin A, Audifas G, Abass A and Tomlins K 2020 Women eat more rice and banana: the influence of gender and migration on staple food choice in east africa. Ecol. Food Nutr. 59: 506-524.

Bugaud C, Daribo M, Deauté M, Telle N and Dubois C 2009 Relative importance of location and period of banana bunch growth in carbohydrate content and mineral composition of fruit. Fruits 64: 63-74.

Byarugaba-Bazirake G 2008 The effect of enzymatic processing on banana juice and wine. $\mathrm{PhD}$ thesis, Stellenbosch University, Stellenbosch.

Chen F, Liu X and Chen L 2009 Developmental changes in pulp organic acid concentration 
and activities of acid-metabolising enzymes during the fruit development of two loquat (eriobotrya japonica lindl.) cultivars differing in fruit acidity. Food Chem. 114: 657-664.

Cordenunsi BR and Lajolo FM 1995 Starch breakdown during banana ripening: sucrose synthase and sucrose phosphate synthase. $J$. Agric. Food Chem. 43: 347-351.

Escalante-Minakata P, Ibarra-Junquera V, Chávez-Rodríguez AM, Ornelas-Paz JDJ, Emparan-Legaspi MJ, Pérez-Martínez JD and Villavelázquez-Mendoza CI 2013 Evaluation of the freezing and thawing cryoconcentration process on bioactive compounds present in banana juice from three different cultivars. Int. J. Food Eng. 9: 445-455.

FAOSTAT 2019 http://www.fao.org/faostat/en/\#data/QCL. Accessed on 30 July 2021

Gensi R, Kyamuhangire, W and Carasco JF 1994 Traditional production and characteristics of banana juice in Uganda. In: African Crop Science conference proceedings 1: 356-359.

Hill SA and Rees T 1993 Fluxes of carbohydrate metabolism in ripening bananas. Planta 192: 52-60.

Karamura DA, Karamura EB and Tinzaara W 2012 Banana cultivar names, synonyms and their usage in eastern africa. Bioversity International, Kampala, Uganda.

Kibazohi O, Kyamuhangire W, Kaunga DL and Rokoni C 2017 Process improvement for mechanical extraction of low-viscosity clear banana juice. Afr. J. Food Sci. 11: 291-295.

Kyamuhangire W, Krekling T, Reed E and Pehrson R 2006 The microstructure and tannin content of banana fruit and their likely influence on juice extraction. J. Sci. Food Agric. 86: 1908-1915.

Kyamuhangire W, Myhre H, Sørensen HT and Pehrson R 2002 Yield, characteristics and composition of banana juice extracted by the enzymatic and mechanical methods. J. Sci. Food Agric. 82: 478-482.

Lee WC, Yusof S, Hamid NSA and Baharin BS 2006 Optimizing conditions for hot water extraction of banana juice using response surface methodology (RSM). J. Food Eng.
75: 473-479.

Lokesh V, Divya P, Puthusseri B, Manjunatha G and Neelwarne B 2014 Profiles of carotenoids during post-climacteric ripening of some important cultivars of banana and development of a dry product from a high carotenoid yielding variety. LWT-Food Sci. Technol. 55: 59-66.

Majaliwa N, Kibazohi O and Alminger M 2019 Optimization of process parameters for mechanical extraction of banana juice using response surface methodology. J. Food Sci. Technol. 56: 4068-4075.

Majaliwa N, Kibazohi O and Alminger M 2021 Effect of cultivar and ripening on the polyphenol contents of East African highland bananas (Musa spp.). Int. Food Res. J. 28(3): 479-488.

Newilah GN, Tomekpe K, Fokou E and Etoa FX 2009 Physicochemical changes during ripening of bananas grown in cameroon. Fresh Prod. Global Science Books 3(1): 6470.

NPHMS 2019 National postharvest management strategy. https://www.kilimo.go.tz/index.php/en/resou rces/view/national-postharvest-managementstrategy. Accessed on 30 July 2021.

Ssamula A, Arinaitwe G and Mukasa SB 2015 Banana juice as an alternative energy source for banana in vitro growth medium. Afr. Crop Sci. J. 23: 59-66.

Tapre AR and Jain RK 2012 Study of advanced maturity stages of banana. Int. J. Adv. Eng. Res. Stud. 1: 272-274.

Tapre AR and Jain RK 2014 Pectinases: Enzymes for fruit processing industry. Int. Food Res. J. 21: 447-453.

Wall MM 2006 Ascorbic acid, vitamin A, and mineral composition of banana (Musa sp.) and papaya (Carica papaya) cultivars grown in Hawaii. J. Food Compos. Anal. 19: 434445.

Zulkifli N, Hashim N, Abdan K and Hanafi M 2019 Application of laser-induced backscattering imaging for predicting and classifying ripening stages of "berangan" bananas. Comput. Electron Agric. 160: 100107. 